\title{
Credit Access and Urban Regeneration in the United States
}

\author{
Alan W. Dyer ${ }^{1, a}$ \\ ${ }^{1}$ Northeastern University Boston, Department of Economics Massachusetts 02115 USA \\ aa.dyer@neu.edu
}

\begin{abstract}
Keywords: Appalachian Regional Commission, Boston Community Venture Fund, Community Development Corporation (CDC), Community Development Financial Institution (CDIF), Credit Creation, Economic Growth, Entrepreneur, Financial Intermediary, Innovation, Joseph Schumpeter.
\end{abstract}

\begin{abstract}
A key objective of the Commercial Local Urban Districts (CLUD) project is to explore different ways in which local economic activity can serve as a catalyst for urban regeneration. One approach to realizing this objective is to examine the linkages between local commercial activity and the broader urban environment, including various types of public private partnerships and their role in fostering local economic development. In particular, it is widely accepted among economists that a healthy commercial sector depends, among other things, on a reliable system for the creation and distribution of credit.
\end{abstract}

\section{The Problem}

One of the questions motivating the research agenda of CLUDs is whether or not it is possible to devise economic growth strategies centered on local and regional initiatives rather than on global and national ones. The reason for emphasizing local and regional economic growth strategies is that the overall goal of CLUDs is to explore new tools for local urban regeneration broad enough to be applied in a variety of cultural and historical milieus, yet sensitive enough to capture the unique qualities of different locales. Specifically, local strategies can draw on a variety of market-based development initiatives that draw on community resources without waiting on national and global capital to trickle down [1].

One approach to studying the processes of economic growth and development that stresses the importance of local and regional factors is Joseph A. Schumpeter's theory of the entrepreneur and innovation [2]. Schumpeter's ideas can be used as a framework for identifying important economic means of urban regeneration by focusing our analytical attention on those circumstances that serve best to create and sustain a local entrepreneurial culture.

Various regional and local experiments with entrepreneur-based strategies of development predate the CLUDs project. Interesting and well-documented examples of these experiments in the United States are associated with the activities of the Appalachian Regional Commission [3]. In addition, several participants at President Barack Obama's May 2010 Presidential Summit on Entrepreneurship raised theme similar to those of the CLUDs project. Jerry Yang, co-founder of Yahoo!, told participants that in order for entrepreneurs to flourish their needs to be "an entire ecosystem" that includes "education, capital, and research and development"[4]. Ehab Abdou, from the Brookings Institution's Middle East Youth Initiative, echoed Yang's view of what it means to create a culture of entrepreneurship and outlined the work to be done in a series of questions: "What kind of networks does it establish? What kinds of funds will come out of it? What kind of ... concrete recommendations for legal reforms need to take place?" [5].

The relationship between economic development and a vibrant local culture of entrepreneurs can be expressed in simple terms: entrepreneurs are those individuals who "revolutionize" the local economy through innovation, which means the introduction of new products, new technologies, or new markets [6].

Perhaps the single most important institutional requirement in order for entrepreneurs to succeed in their role as economic innovators is access to financial means in order to hire the resources needed to produce and market products [7]. The financial sector in a community that lacks either an 
active, homegrown commercial sector or the means to attract outside commercial interests is unlikely to have sufficient funds or the inclination to take a risk on novice entrepreneurs. The obvious problem in such communities is how to stimulate new entrepreneurs when the requisite financial means and institutions are absent. While the funds necessary in order to stimulate innovation may come from public sources, the aim of CLUDs is to explore novel methods through which local entrepreneurs can obtain financing with the help of institutions that are either private or some form of public-private collaboration.

\section{Private credit creation}

Entrepreneurs typically seek financing from a bank or other financial intermediary in order to hire the labor, capital, and raw materials required to start a new enterprise. Assume that a local start-up entrepreneur must rely on local commercial banks in order to secure the financing necessary to get his project off the ground because he has neither his own funds nor access to more complex types of financial intermediaries. Banks are, of course, profit-seeking enterprises in the business of buying and selling a product called "credit." A bank "buys" credit when it exchanges its debt (a liability of the bank in the form of an interest-bearing account) for the assets of a depositor (now the owner of the bank's liability and not the funds they deposited at the bank).

A bank "sells" credit whenever it agrees to loan money, in our case, to an entrepreneur. The interest rate the bank charges for its loan is the "price" the borrower must pay when he buys the banks "product".

The metric a bank uses in order to price the credit it sells to entrepreneurs is of particular importance to answering the question of whether or not the creation of an entrepreneurial culture is a realistic tool of urban regeneration. Banks consider a variety of factors when determining the prices they will charge for credit.

The ultimate goal of a bank is to earn a profit on the spread between what it costs them to "produce" credit (what they must pay when they "buy" credit in the form of deposits from their customers) and what they earn when they sell credit (what the entrepreneur or other borrowers must pay when a bank "sells" them credit in the form of a loan).

Banks in communities with little or no economic growth are likely to have a low and predictable volume of depositor activity, meaning that their costs of producing credit are known. However, these same economic conditions suggest a high price for the credit sold by banks. The metric for setting the price of credit includes, for example, the creditworthiness of the borrower, the level and sustainability of the local demand for new product, as well as intangibles such as local tastes and preferences.

In relatively poor communities the outcome of applying this pricing metric will often lead to little if any credit creation. The risk and uncertainty of selling credit to an entrepreneur, who by definition engages in a risky and uncertain form of economic activity, are simply too high from the bank's point of view. If possible, it makes more commercial sense for the local bank to invest its assets elsewhere where the returns are less risky and greater than they are in the local community. In general, the expectation that bankers will calculate that it is profitable to make loans to untested entrepreneurs for untested products is not good.

Consequently, if the aim is to create an entrepreneurial culture, stimulate local economic development, and open a path to urban regeneration, institutions other than traditional commercial banks or public agencies must serve the important role of providing access to credit, the lifeblood of entrepreneurs.

\section{Alternative financial institutions}

One form of urban management tool identified in several of the case studies carried out in Boston is the community development corporation (CDC). Broadly defined, a CDC is a non-profit organization incorporated for the purpose of stimulating and supporting community development in a well-defined geographical location, using a variety of economic, social, and educational tools. 
Examples of CDCs in the Boston area include the Asian community development corporation, the Jamaica Plain neighborhood development corporation, and the Codman Square neighborhood development corporation.

One type of CDC, known as community development financial institutions (CDFIs), is of particular interest to the challenge of creating a entrepreneurial culture in areas where existing financial institutions are unable to justify financing entrepreneurs according to the metrics employed by a for-profit enterprise. The Boston Community Venture Fund, part of Boston Community Capital, is an excellent example of the sort of institution that can support a broad range of financial services in communities that lack an active financial sector. In the words of the Boston Community Venture Fund:

BCVF . . . invests throughout the Northeast, providing equity investments in high-potential businesses that create a "double bottom-line" of financial and social returns. We view job creation as a primary indicator of social return but also invest in businesses that provide quality goods and services to lower-income communities or other disadvantaged populations, enhance the stability of lower-income or rural neighborhoods, or are women or minority-owned business enterprises. In addition, we seek companies that produce products that enhance the environment or reduce pollution [8].

There are a number of different forms in which CDFIs operate in communities across the United States [9]. The list below illustrates the variety of options available for creating local financial institutions devoted to economic development, in particular, and urban regeneration, in general. Included are the names of one of the first organizations created in each category and the date it was founded.

1. Community Development Banks: South Shore Bank in Chicago, 1973

2. Community Development Credit Unions: Center for Community Self-Help, Durham, North Carolina, 1980

3. Community Development Loan Funds: nonprofit financial intermediaries, Revolving Loan Fund operated by the Institute for Community Economics, Springfield, MA, 1979

4. Micro-enterprise Loan Funds: 340 micro-enterprise programs in 46 States helped start 40,000 businesses, 1998

\section{Conclusion}

An important finding of the research carried out in Boston is the way in which public private partnerships provide a foundation for urban regeneration, often focusing on economic factors as the catalyst for sustainable local initiatives. As an extension of this research it would be interesting to explore further the potential for community development financial institutions to serve as the spark of local financial development. It would enhance the analytical scope of the CLUDs project if the research could demonstrate how and to what extent CDFIs can improve credit access, stimulate entrepreneurial culture, and support a broader process of urban regeneration.

\section{References}

[1] R. Weissbourd and R. Bodini: Market-based Community Economic Development, March (2005). The Brookings Institution Metropolitan Policy Program

[2] J.A. Schumpeter, The Theory of Economic Development, trans. By Redvers Opie, Harvard University Press, Cambridge (1934)

[3] D. Markley, et al. April 2008: Creating an Entrepreneurial Appalachian Region: Findings and Lessons from an Evaluation of the Appalachian Regional Commission's Entrepreneurship Initiative 1997-2005, Center for Rural Entrepreneurship. 
[4] D. Alexander: Obama fulfills Cairo pledge with entrepreneur summit, 26 April 2010, Information on http://www.reutors.com/

[5] D. Alexander: Obama fulfills Cairo pledge with entrepreneur summit, 26 April 2010, Information on http://www.reutors.com/

[6] J. A. Schumpeter: The Theory of Economic Development, trans. By Redvers Opie, Harvard University Press, Cambridge (1934)

[7] J. A. Schumpeter: Business Cycles. McGraw-Hill, New York (1939)

[8] Boston Community Venture Fund. 2012. Quotation found at http://www.bostoncommunitycapital.org/what/venture-fund

[9] Democracy Collaborative: Your Community's Economic Development: A Guide to Innovative State and Local Policies, September (2003), Democracy Collaborative, University of Maryland 